\title{
A ORIENTAÇÃO PRESTADA À COMUNIDADE SOBRE OS RISCOS DA INGESTÃO EXCESSIVA DE PASTAS DENTAIS FLUORETADAS POR CRIANÇAS DE ATÉ 6 ANOS
}

Saulo Kfouri LOPES; Ranulfo DUARTE NETO; Maria da Graça Kfouri LOPES

A importância de compostos fluoretados na prevenção da cárie é indiscutível. A instrução à comunidade sobre sua ingestão é pouco difundida. Sua principal conseqüência é a fluorose, que se qualifica como uma patologia que afeta a amelogênese dentária. Em casos mais graves, pode ocasionar problemas sistêmicos manifestados no tecido ósseo ou em forma de intoxicação aguda. Considerando-se esta falta de instrução, desenvolveu-se uma pesquisa na Creche Municipal Santos Andrade. Por meio de questionários destinados às crianças de 5 anos e seus pais, tentou-se obter informações sobre seus hábitos. As perguntas eram: Que pasta a criança usava na escovação; se a criança ingeria o dentifrício; e se a mãe já tinha sido informada sobre a conseqüência desta ingestão. Aos cuidadores da creche e THD da US, foi perguntado que tipo de orientação era dada aos responsáveis sobre a ingestão excessiva de pastas dentais com flúor. Os resultados parciais obtidos com a pesquisa são que: $100 \%$ das crianças usam pasta com flúor, $55.5 \%$ engolem pasta todo dia e $55.6 \%$ dos pais não tinham informação sobre as conseqüências desta ingestão. Assim o principal objetivo, não é apenas coletar informações, e sim, inteirar-se do nível de informação sobre a fluorose. 